\title{
Oncolytic Engineering of ICP34.5 and LAT of Herpes Simplex Virus Type 1
}

\author{
Wenqi Cai ${ }^{1,2 *}$, Ying Zhang1,2*, Qi Huang1,2*, Ying Xiang1,2\#, Hongwu Xin ${ }^{1,2 \#}$ \\ ${ }^{1}$ Laboratory of Oncology, Center for Molecular Medicine, School of Basic Medicine, Health Science Center, Yangtze University, \\ Jingzhou, China \\ ${ }^{2}$ Department of Biochemistry and Molecular Biology, School of Basic Medicine, Health Science Center, Yangtze University, \\ Jingzhou, China \\ Email: "xying316@163.com, "hongwu_xin@126.com
}

How to cite this paper: Cai, W.Q., Zhang, Y., Huang, Q., Xiang, Y. and Xin, H.W. (2021) Oncolytic Engineering of ICP34.5 and LAT of Herpes Simplex Virus Type 1. Yangtze Medicine, 5, 106-116. https://doi.org/10.4236/ym.2021.52011

Received: June 17, 2020

Accepted: April 12, 2021

Published: April 15, 2021

Copyright (c) 2021 by author(s) and Scientific Research Publishing Inc. This work is licensed under the Creative Commons Attribution International License (CC BY 4.0).

http://creativecommons.org/licenses/by/4.0/

\begin{abstract}
Oncolytic virus (OV) is a kind of virus that can preferentially infect and kill tumor cells. The second oncolytic virus drug was oncolytic herpes simplex virus (oHSV) Talimogene Laherparepvec (T-VEC). HSV-1 infectious cell culture protein 34.5 (ICP34.5) and latency-associated transcript (LAT) genes are closely related to virus selective infection and latent infection. Their engineering is essential for constructing efficient and safe oHSV. We summarized the mechanisms of ICP34.5 and LAT in the course of HSV-1 infection and reviewed the engineered oHSVs. We are aimed to provide an insight in developing oHSV in the future.
\end{abstract}

\section{Keywords}

Herpes Simplex Virus, Oncolytic Herpes Simplex Virus, Latency-Associated Transcript, ICP34.5

\section{Introduction}

Cancer is a serious disease which threatens human health and life. Traditional chemotherapy, radiotherapy or surgical procedure is accompanied by toxic side effect, drug resistance [1]. With the development of precision medical technology, chimeric antigen receptor $\mathrm{T}$ cell immunotherapy (CAR- $\mathrm{T}$ ), immune checkpoint suppression therapy, oncolytic virus (OV) therapy and other therapies have also made significant progress [2]. OVs are promising treatments for many kinds of tumor [3]. They can kill tumor cells without cross-resistance with other

*Authors contributed equally.

\#Corresponding author. 
therapies, and can produce a synergistic effect with other therapies [4].

In clinical trials, adenoviruses, alphaviruses, herpes simplex viruses, newcastle disease viruses, etc. have been applied as engineered OV vectors. HSV-1 is a double-stranded DNA virus with a long genome (152 kb) [5]. HSV-1 can carry multiple foreign genes because it has about $30 \mathrm{~kb}$ of non-essential genes [6]. In addition, the replication of HSV-1 in the host cells does not cause insertional mutagenesis. Above-mentioned factors make HSV-1 a good candidate for oncolytic virus engineering [7]. The modified oncolytic herpes simplex virus (oHSV) can specifically target tumor cells without damaging normal tissue cells and further release progeny viruses after replicating in tumor cells [8]. oHSV-1 has been confirmed to have the positively therapeutic efficacy and safety in clinical trials [9].

\section{Structure and Function of ICP34.5 and LAT}

A wild type HSV-1 enters a host cell through the binding of virus surface glycoproteins and host cell surface receptors (Herpes virus entry mediator) [10]. Humans infected with HSV-1 may produce a series of skin lesions and neurotoxicity. Subsequently, HSV-1 establishes latency infection in the nervous system [11]. HSV-1 can be latent for several years or even a lifetime [12].

ICP34.5 is a neurovirulence factor. It plays a crucial role in viral replication and anti-host response [13]. The viral protein ICP34.5 contains four domains [14] [15]: 1) Beclin 1 region can inhibit the initiation of host autophagy; 2) TANK-binding kinase (TTBK1) region can inhibit the induction of type I interferon (IFN) response; 3) The C-terminal domains 3 and 4 retarget the host phosphatase PP1 $\alpha$ to eIF $2 \alpha$ for eIF2 $\alpha$ dephosphorylation and translation activation. Recently, Rubio RM et al. reported that NOP53 could directly the interaction with ICP34.5. Cytoplasmic NOP53 promotes the recruitment of PP1 $\alpha$ through ICP34.5, which leads the dephosphorylation of eIF2 $\alpha$ for effective

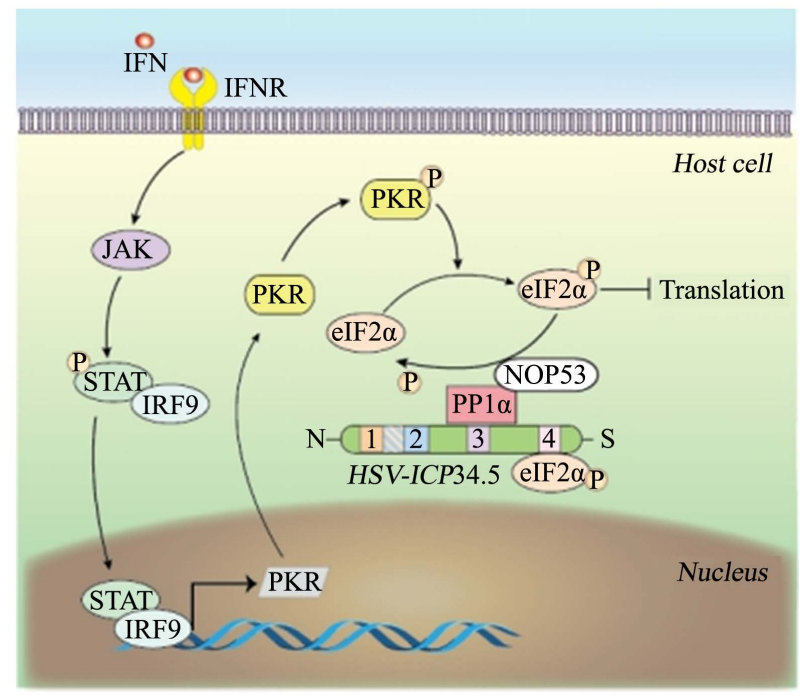

Figure 1. ICP34.5 is involved in anti-host innate immune response. 
virus replication [16]. During HSV infection (Figure 1), the host cells bind type I IFN through the IFN receptor, activate the JAK-STAT pathway and upregulate protein kinase $\mathrm{R}$ (PKR). Then PKR is activated by its ligand, which will cause phosphorylation of the host's translation initiation factor eIF $2 \alpha$, thereby inhibiting HSV replication and host protein synthesis [17]. However, the C-terminal domain of HSV ICP34.5 protein can bind to host phosphatase PP1 $\alpha$ and relocate it to eIF $2 \alpha$, leading to dephosphorylation and restoration of mRNA translation [18] [19]. Type I IFN response is blocked by ICP34.5 while antagonizing the PKR IFN response, which is important for HSV-1 infection [20] [21].

Latency-associated transcript (LAT) regulates HSV-1 latency and reactivation in sensory neurons [22], which is related to the genetic structure of LAT [23]. LAT consists of $8.3 \mathrm{~kb}$ primary transcripts. Previous studies have shown that the $2.0 \mathrm{~kb}$ major LAT is an intron of the $8.3 \mathrm{~kb}$ transcripts, which is extraordinarily stable during lytic and latent infection due to its special non-consensus guanosine branchpoint [13]. Furthermore, the $2.0 \mathrm{~kb}$ major LAT RNA undergoes further splicing within the neuron during HSV-1 latent period, eventually producing another $1.5 \mathrm{~kb}$ stable RNA species. The $6.3 \mathrm{~kb}$ exon product of the first splice in LAT and the $0.5 \mathrm{~kb}$ intron product of the second splice are difficult to detect [24]. A study has shown that exon 1 region of LAT is a critical factor to block apoptosis [25]. LAT functions as a primary microRNA (miRNA) precursor that encodes several distinct miRNAs in HSV-1 infected cells. A study has shown [26] that at least two primary miRNA precursors were found in the latent infected neurons, which may be related to the activation and maintenance of the latentcy of the virus. Another study has shown [27] that the miRNA encoded by HSV-1 LAT gene can suppress the apoptosis of infected cells by regulating the transforming growth factor- $\beta$ signal transduction, thus promoting the latent infection of the virus. In addition, a study has shown [28] that HSV-1 latency inhibits dendritic growth in sympathetic neurons.

HSV latency and toxicity in neurons are crucial issues in the treatment of HSV infection and engineering of effective and safe oHSVs. HSV LAT and ICP34.5 related research provided an important basis for HSV treatment and oHSV engineering in the future.

During the period of viral infection, the host cell activates the JAK-STAT pathway, up-regulates PKR kinase via the IFN receptor and eventually phosphorylates eIF $2 \alpha$, which cause the host cell synthesis inhibition. However, the HSV-1 ICP34.5 can prevent this process through binding to PP1 $\alpha$ and dephosphorylating eIF2 $\alpha$. At the same time, NOP53 can promote the binding of ICP34.5 to PP1 $\alpha$. The domains 1 - 4 of ICP34.5 are shown.

\section{Oncolytic Engineering of ICP34.5 and LAT of HSV}

Studies have shown that the deletion of the ICP34.5 gene allowed oHSV to rep- 
licate selectively in specific tumors, which is related to PKR activity [29]. Specifically, this is caused by the fact that the activity of PKR inhibitor MAPK/ERK kinase (MEK) is generally high in tumor cells. ICP34.5 and LAT are key genes for HSV-1 neuroinvasiveness and reactivation of latency [30]. Perng G et al. [31] reported the deletion of HSV-1 LAT genes. The absence of LAT and ICP34.5 prevents the virus from latency and reactivation, which means there has a long-term safe margin after treatment [11]. Therefore, LAT and ICP34.5 engineering are essential for the construction of oHSV. More importantly, HSV-1 ICP34.5 is overlapped with LAT at their gene locus. LAT and ICP34.5 are encoded on the opposite strand.

Here we review the relevant oHSVs with LAT and ICP34.5 engineering (Table 1 and Figure 2). At the same time, we also illustrate a new 93aa open reading frame (ORF) RL1A that has been found to be overlap with the ICP34.5 locus [32]. Currently, HSV-1 strains F and 17 are typically used as vectors in clinical practice and clinical trials.

Table 1. Oncolytic engineering of ICP34.5 and LAT of HSV-1.

\begin{tabular}{|c|c|c|c|c|c|c|c|}
\hline Virus & Name & Tumor & $\begin{array}{l}\text { Modified HSV } \\
\text { gene }\end{array}$ & $\begin{array}{c}\text { ICP34.5/LAT } \\
\text { (bp) }\end{array}$ & $\begin{array}{l}\text { Additional } \\
\text { modification }\end{array}$ & $\begin{array}{l}\text { Replication } \\
\text { activity } \\
\text { reduction }\end{array}$ & Ref \\
\hline $\begin{array}{l}\text { HSV-1 } \\
\text { (F) }\end{array}$ & M032 & Brain tumors & ICP34.5 & $\begin{array}{c}2 \mathrm{~kb} \text { replaced in the } \\
\gamma 34.5 \text { and ORF P. }\end{array}$ & IL12 & About 100 times & [35] \\
\hline $\begin{array}{l}\text { HSV-1 } \\
\text { (F) }\end{array}$ & NG34 & Glioblastoma & $\begin{array}{c}\text { ICP6, } \\
\text { ICP34.5 }\end{array}$ & $\begin{array}{c}\text { 1000-bp deletions in } \\
\text { both } \gamma 34.5 \text { genes }\end{array}$ & GADD34 & About 100 times & [31] \\
\hline $\begin{array}{l}\mathrm{HSV}-1 \\
\quad(\mathrm{~F})\end{array}$ & G47 $\Delta$ & Melanoma & $\begin{array}{c}\text { ICP34.5 } \\
\text { ICP6 } \\
\text { ICP47 }\end{array}$ & $\begin{array}{l}\text { 1000-bp deletions } \\
\text { in both } \gamma 34.5 \text { genes }\end{array}$ & - & About 100 times & [33] \\
\hline $\begin{array}{l}\mathrm{HSV}-1 \\
(\mathrm{~F})\end{array}$ & NV1020 & $\begin{array}{c}\text { Metastatic } \\
\text { colorectal cancer }\end{array}$ & $\begin{array}{c}\text { ICP34.5 } \\
\text { ICP4 } \\
\text { ICP0 }\end{array}$ & $\begin{array}{l}\Delta 1.5 \mathrm{~kb} \text { over the } \\
\text { joint region } \\
(\mathrm{ICP} 34.5 / 4 / 0)\end{array}$ & - & About 100 times & [34] \\
\hline $\begin{array}{l}\text { HSV-1 } \\
\text { (F) }\end{array}$ & G207 & Glioblastoma & $\begin{array}{c}\text { ICP34.5 } \\
\text { deletion ICP6 }\end{array}$ & $\begin{array}{l}\text { 1000-bp deletions } \\
\text { in both } \gamma 34.5 \text { genes }\end{array}$ & LacZ & About $10-100$ times & [32] \\
\hline $\begin{array}{l}\text { HSV-1 } \\
(17)\end{array}$ & HSV1716 & Solid cancers & $\begin{array}{l}\text { ICP34.5 } \\
\text { deletion }\end{array}$ & $\begin{array}{c}\Delta \mathrm{ICP} 34.5 \\
125,213-125,972\end{array}$ & - & About $10-100$ times & [36] \\
\hline $\begin{array}{l}\text { HSV-1 } \\
(17)\end{array}$ & RH018 & $\begin{array}{l}\text { Gliosarcoma, } \\
\text { melanoma }\end{array}$ & $\begin{array}{c}\text { ICP47 } \\
\text { ICP34.5 }\end{array}$ & $\begin{array}{c}\Delta \mathrm{ICP} 34.5 \\
124,954-125,726\end{array}$ & $\begin{array}{l}\text { GALV-GP-R, } \\
\text { MGM-CSF }\end{array}$ & Not mentioned & [11] \\
\hline $\begin{array}{l}\text { HSV-1 } \\
\text { (JS-1) }\end{array}$ & T-VEC & $\begin{array}{l}\text { Medulloblastoma } \\
\text { Melanoma }\end{array}$ & $\begin{array}{l}\text { ICP34.5 deletion, } \\
\text { US11 deletion }\end{array}$ & $\begin{array}{c}\Delta \mathrm{ICP} 34.5 \\
124,948-125,713\end{array}$ & GM-CSF & About $10-100$ times & [37] \\
\hline $\begin{array}{l}\mathrm{HSV}-1 \\
(\mathrm{CL} 1)\end{array}$ & OrienX010 & Glioblastoma & $\begin{array}{l}\text { ICP34.5 deletion, } \\
\text { ICP47 deletion, }\end{array}$ & $\begin{array}{c}\Delta \mathrm{ICP} 34.5 \\
\text { completely deleted }\end{array}$ & $\begin{array}{l}\text { GM-CSF } \\
\text { insertion }\end{array}$ & Not mentioned & [38] \\
\hline $\begin{array}{c}\text { HSV-1 } \\
\text { (McKrae) }\end{array}$ & DM33 & $\begin{array}{l}\text { Glioblastomas } \\
\text { Brain tumors }\end{array}$ & $\begin{array}{c}\text { Deleted } \\
\gamma 34.5 \text { and LAT }\end{array}$ & $\begin{array}{c}\Delta \text { LAT1 } \\
76 \text { to } 1667 \\
\text { (Contains the } \\
\text { entire ICP34.5) }\end{array}$ & $\begin{array}{l}\text { LAT was } \\
\text { replaced } \\
\text { by GFP }\end{array}$ & Not mentioned & [17] \\
\hline $\begin{array}{l}\text { HSV-1 } \\
\text { (HF) }\end{array}$ & HF10 & $\begin{array}{c}\text { Superficial cancers, } \\
\text { melanoma }\end{array}$ & UL56 LAT & $\begin{array}{l}116.515 \text { to } 120.346 \\
\text { (UL56 and LAT) }\end{array}$ & $\begin{array}{l}\text { UL52, UL53, } \\
\text { UL54, UL55 }\end{array}$ & Not mentioned & [39] \\
\hline
\end{tabular}




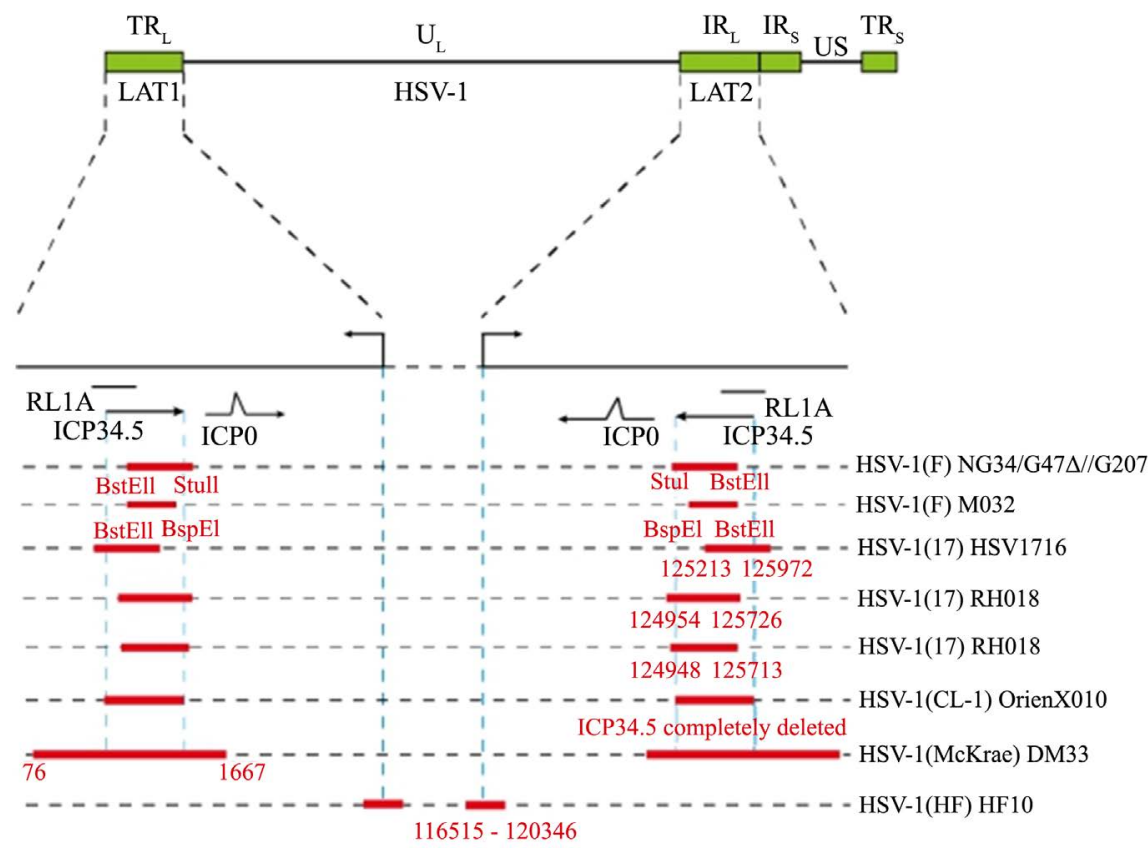

Figure 2. The relative positions of the ICP34.5, LAT and RL1A in different HSV strains.

Previous studies have shown that people have carried out different engineering on the HSV-F strain: NG34, G47 , NV1020 and G207. These oHSVS belong to the second generation oHSV, with several gene deletions or insertions. oHSV NG34 contains the ICP6 and ICP34.5 deletions, and additionally inserts the human growth arrest and DNA damage-34 (GADD34) gene. Research by Nakashima $\mathrm{H}$ et al. showed that oHSV NG34 was safe and effective in a glioblastoma (GBM) mouse model [33]. G207 contains a deletion of the ICP34.5 gene and a disrupting lacZ insertion within the UL39 gene. Rencently, Bernstock JD et al. [34] demonstrated the safety and effectiveness of G207 in advanced cerebellar malignancies. Similarly, G47 $\Delta$ further deletes the ICP47 gene based on G207. The research's result of Todo $\mathrm{T}$ et al. showed that G47 $\Delta$ comparing with G207 had a higher amount of replication in test cells and a stronger killing effect of tumor cells. ICP47 has the function of blocking the major histocompatibility complex class I antigen presentation pathway. Deletion of ICP47 enhances T cell activity and produces a stronger killing effect of tumors. G47 $\Delta$ has become one of the most promising oncolytic virus [35]. In addition, oHSV-1 NV1020 has multiple gene deletions (LAT, ICP34.5, ICP4 and ICP0). The results of Eevarghese SK showed that NV1020 stabilized liver metastases with minimal toxicity in metastatic colorectal cancer (mCRC) [36]. M032 also contained ICP34.5 deletion, but the difference is that it contained an extra insertion of gene IL12. It was shown that M032 was safe and effective [37].

The HSV-1 (17) strain is also one of the most common strains for oHSV construction. Seprehvir (HSV1716) contained ICP34.5 deletion and cannot replicate in normal cells, which belongs to the first generation of oncolytic HSV. At the same time, HSV1716 can also express thymidine kinase. Recent- 
ly, the research's result of Streby KA et al. had shown that HSV1716 was safe and effective in treating juvenile malignant tumors [38]. HSV-1 RH018 contains the ICP34.5 and ICP47 deletion, and additional insertion of the glycoprotein of the gibbon leukemia virus (GALV-GP). Moreover, HSV-1 RH018 shows significant anti-tumor effect when it is used in combination with the immune checkpoint PD1/L1 inhibitor. The phenomenon reconfirms that the oncolytic virus can effectively combine with other treatment methods to treat patients [29].

Other oHSVs include: T-VEC (JS-1), OrienX010 (CL-1), DM33 (McKrae), and HF10 (HF). Talimogene laherparepvec (T-VEC) includes the deletion of two ICP34.5 genes and ICP47 gene. Meanwhile, the gene encoding human granulocyte-macrophage colony stimulating factor (GM-CSF) replaced the ICP34.5-encoding sequences. The therapeutic effect of T-VEC on melanoma in clinical trials has been demonstrated [39]. In addition, OrienX010 is based on the HSV-1 CL1 strain, and expresses GM-CSF. Studies have shown that OrienX010 treatment has a well toleration and effectiveness [40]. Samoto K. et al. constructed oHSV-1 DM33 which contained ICP34.5 and LAT deletion and the green fluorescent protein gene insertion. A study showed the efficacy and safety of DM33 in the treatment of gliomas [12]. A series of mutations in the oHSV HF10 genome lead to the non-expression of multiple gene products including LAT [30]. Recent studies have shown that the treatment group of HF10 and dacarbazine has more IFN- $\gamma$ secretion, and HF10 has shown its efficacy in a variety of tumors [41].

We have further detailed the specific sites of ICP34.5 and LAT deletion in Table 1 and Figure 2, which will help the engineering of oHSVs using different strains in the future. At present, we have done a great deal of researches on the comparison between the same genes of different strains [11] [42] [43] [44], which will help construct new oHSVs in the future.

\section{Conclusion and Perspective Views}

We summarized the structure and function of ICP34.5 and LAT in HSV-1. We also reviewed the engineering of genes related to latent infection and neurovirulence, ICP34.5 and LAT. These are crucial for the construction of oncolytic viruses in the future. The deletion of ICP34.5 leads to oHSV selectively replicate in tumors, but the amount of oHSV replication also decreases significantly [45]. In order to cope with the decrease of oHSV replication caused by the lack of ICP34.5, some strategies need to be developed. The absence of HSV-1 ICP47 enhances the presentation of major histocompatibility complex (MHC) class I antigens on infected cells, while increasing the anti-tumor effects of HSV mutants [46] [47]. Most oHSVs [29] with deletion of the gene encoding ICP34.5 (part of LAT) promote tumor selectivity and reduce virus toxicity, while insertion of therapeutic genes (such as GM-CSF) increases the anti-tumor effect of oHSV. According to previous research, HSV-1 has approximately 80 ORFs [48]. 
Recently, a report at NUTURE COMMUNICATIONS [32] showed about 284 ORFs in HSV-1, among which 46 novel large ORFs are found. A 93aa ORF (RL1A) was found in the ICP34.5 locus.

T-Vec has shown ideal efficacy and safety in clinical practice [49]. In clinical studies [50], researchers found that the efficacy of oncolytic virus monotherapy varies greatly, which may be related to the host's antiviral response. In order to overcome the shortcomings of oncolytic virus single-agent therapy, people consider the combined application of oncolytic virus with other immunotherapies, and obvious curative effects have been observed [51]. New discoveries above will provide powerful basis for the future development of oHSV.

\section{Conflicts of Interest}

No conflict of interest exits in the submission of this manuscript, and the manuscript is approved by all authors for publication. I would like to declare on behalf of my co-authors that the work described was original research that has not been published previously, and not under consideration for publication elsewhere, in whole or in part.

\section{References}

[1] Salgado, R., Moore, H., Martens, J.W.M., et al. (2018) Steps Forward for Cancer Precision Medicine. Nature Reviews Drug Discovery, 17, 1-2. https://doi.org/10.1038/nrd.2017.218

[2] Liu, D. (2019) CAR-T “the Living Drugs", Immune Checkpoint Inhibitors, and Precision Medicine: A New Era of Cancer Therapy. Journal of Hematology \& Oncology, 12, 113. https://doi.org/10.1186/s13045-019-0819-1

[3] Wang, D., Wang, X.W., Peng, X.C., et al. (2018) CRISPR/Cas9 Genome Editing Technology Significantly Accelerated Herpes Simplex Virus Research. Cancer Gene Therapy, 25, 93-105. https://doi.org/10.1038/s41417-018-0016-3

[4] Bommareddy, P.K., Shettigar, M. and Kaufman, H.L. (2018) Integrating Oncolytic Viruses in Combination Cancer Immunotherapy. Nature Reviews Immunology, 18, 498-513. https://doi.org/10.1038/s41577-018-0014-6

[5] Wertheim, J.O., Smith, M.D., Smith, D.M., et al. (2014) Evolutionary Origins of Human Herpes Simplex Viruses 1 and 2. Molecular Biology and Evolution, 31, 2356-2364. https://doi.org/10.1093/molbev/msu185

[6] Lawler, S.E. and Chiocca, E.A. (2015) Oncolytic Virus-Mediated Immunotherapy: A Combinatorial Approach for Cancer Treatment. Journal of Clinical Oncology, 33, 2812-2814. https://doi.org/10.1200/JCO.2015.62.5244

[7] Peters, C. and Rabkin, S.D. (2015) Designing Herpes Viruses as Oncolytics. Molecular Therapy-Oncolytics, 2, Article No. 15010. https://doi.org/10.1038/mto.2015.10

[8] Kaufman, H.L., Kohlhapp, F.J. and Zloza, A. (2015) Oncolytic Viruses: A New Class of Immunotherapy Drugs. Nature Reviews Drug Discovery, 14, 642-662. https://doi.org/10.1038/nrd4663

[9] Yoo, J.Y., Swanner, J., Otani, Y., et al. (2019) Oncolytic HSV Therapy Increases Trametinib Access to Brain Tumors and Sensitizes Them in Vivo. Neuro-Oncology, 
21, 1131-1140. https://doi.org/10.1093/neuonc/noz079

[10] Lazear, E., Whitbeck, J.C., Zuo, Y., et al. (2014) Induction of Conformational Changes at the N-Terminus of Herpes Simplex Virus Glycoprotein D upon Binding to HVEM and Nectin-1. Virology, 448, 185-195.

https://doi.org/10.1016/j.virol.2013.10.019

[11] Zhang, Y., Xin, Q., Zhang, J.Y., et al. (2020) Transcriptional Regulation of Latency-Associated Transcripts (LATs) of Herpes Simplex Viruses. Journal of Cancer, 11, 3387-3399. https://doi.org/10.7150/jca.40186

[12] Samoto, K., Ehtesham, M., Perng, G.C., et al. (2002) A Herpes Simplex Virus Type 1 Mutant with Gamma 34.5 and LAT Deletions Effectively Oncolyses Human U87 Glioblastomas in Nude Mice. Neurosurgery, 50, 599-605. https://doi.org/10.1227/00006123-200203000-00031

[13] Henderson, G., Jaber, T., Carpenter, D., et al. (2009) Identification of Herpes Simplex Virus Type 1 Proteins Encoded within the First $1.5 \mathrm{~kb}$ of the Latency-Associated Transcript. Journal of Neuro Virology, 15, 439-448. https://doi.org/10.3109/13550280903296353

[14] Radtke, K., English, L., Rondeau, C., et al. (2013) Inhibition of the Host Translation Shutoff Response by Herpes Simplex Virus 1 Triggers Nuclear Envelope-Derived Autophagy. Journal of Virology, 87, 3990-3997.

https://doi.org/10.1128/JVI.02974-12

[15] Christensen, M.H., Jensen, S.B., Miettinen, J.J., et al. (2016) HSV-1 ICP27 Targets the TBK1-Activated STING Signalsome to Inhibit Virus-Induced Type I IFN Expression. The EMBO Journal, 35, 1385-1399. https://doi.org/10.15252/embj.201593458

[16] Meng, W., Han, S.C., Li, C.C., et al. (2018) Multifunctional Viral Protein Gamma34.5 Manipulates Nucleolar Protein NOP53 for Optimal Viral Replication of HSV-1. Cell Death \& Differentiation, 9, 103. https://doi.org/10.1038/s41419-017-0116-2

[17] Chen, X., Zhou, Y., Wang, J., et al. (2015) Dual Silencing of Bcl-2 and Survivin by HSV-1 Vector Shows Better Antitumor Efficacy in Higher PKR Phosphorylation Tumor Cells in Vitro and in Vivo. Cancer Gene Therapy, 22, 380-386. https://doi.org/10.1038/cgt.2015.30

[18] La Rosa, F., Agostini, S., Bianchi, A., et al. (2019) Herpes Simplex Virus-1 (HSV-1) Infection Induces a Potent But Ineffective IFN-Lambda Production in Immune Cells of AD and PD Patients. Journal of Translational Medicine, 17, 286. https://doi.org/10.1186/s12967-019-2034-9

[19] Wilcox, D.R. and Longnecker, R. (2016) The Herpes Simplex Virus Neurovirulence Factor Gamma34.5: Revealing Virus-Host Interactions. PLOS Pathogens, 12, e1005449. https://doi.org/10.1371/journal.ppat.1005449

[20] Rosato, P.C. and Leib, D.A. (2015) Neuronal Interferon Signaling Is Required for Protection against Herpes Simplex Virus Replication and Pathogenesis. PLOS Pathogens, 11, e1005028. https://doi.org/10.1371/journal.ppat.1005028

[21] Larsen, I.S. (1974) Study Days in Uppsala: Teaching Aspects in Health and Sickness Care with Reference to Clinical Training. Sygeplejersken, 74, 24-27.

[22] Tang, S., Bertke, A.S., Patel, A., et al. (2008) An Acutely and Latently Expressed Herpes Simplex Virus 2 Viral microRNA Inhibits Expression of ICP34.5, a Viral Neurovirulence Factor. Proceedings of the National Academy of Sciences of the United States of America, 105, 10931-10936. 
https://doi.org/10.1073/pnas.0801845105

[23] Watson, Z.L., Washington, S.D., Phelan, D.M., et al. (2018) In Vivo Knockdown of the Herpes Simplex Virus 1 Latency-Associated Transcript Reduces Reactivation from Latency. Journal of Virology, 92, e00812-18.

https://doi.org/10.1128/JVI.00812-18

[24] Nicoll, M.P., Hann, W., Shivkumar, M., et al. (2016) The HSV-1 Latency-Associated Transcript Functions to Repress Latent Phase Lytic Gene Expression and Suppress Virus Reactivation from Latently Infected Neurons. PLOS Pathogens, 12, e1005539. https://doi.org/10.1371/journal.ppat.1005539

[25] Ahmed, M., Lock, M., Miller, C.G., et al. (2002) Regions of the Herpes Simplex Virus Type 1 Latency-Associated Transcript That Protect Cells from Apoptosis in $V i$ tro and Protect Neuronal Cells in Vivo. Journal of Virology, 76, 717-729. https://doi.org/10.1128/JVI.76.2.717-729.2002

[26] Umbach, J.L., Kramer, M.F., Jurak, I., et al. (2008) MicroRNAs Expressed by Herpes Simplex Virus 1 during Latent Infection Regulate Viral mRNAs. Nature, 454, 780-783. https://doi.org/10.1038/nature07103

[27] Gupta, A., Gartner, J.J., Sethupathy, P., et al. (2006) Anti-Apoptotic Function of a microRNA Encoded by the HSV-1 Latency-Associated Transcript. Nature, 442, 82-85. https://doi.org/10.1038/nature04836

[28] Hamza, M.A., Higgins, D.M. and Ruyechan, W.T. (2006) Herpes Simplex Virus Type-1 Latency Inhibits Dendritic Growth in Sympathetic Neurons. Neurobiology of Disease, 24, 367-373. https://doi.org/10.1016/j.nbd.2006.07.011

[29] Thomas, S., Kuncheria, L., Roulstone, V., et al. (2019) Development of a New Fusion-Enhanced Oncolytic Immunotherapy Platform Based on Herpes Simplex Virus Type 1. Journal for ImmunoTherapy of Cancer, 7, 214. https://doi.org/10.1186/s40425-019-0682-1

[30] Eissa, I.R., Naoe, Y., Bustos-Villalobos, I., et al. (2017) Genomic Signature of the Natural Oncolytic Herpes Simplex Virus HF10 and Its Therapeutic Role in Preclinical and Clinical Trials. Frontiers in Oncology, 7, 149.

https://doi.org/10.3389/fonc.2017.00149

[31] Perng, G.C., Dunkel, E.C., Geary, P.A., et al. (1994) The Latency-Associated Transcript Gene of Herpes Simplex Virus Type 1 (HSV-1) Is Required for Efficient in Vivo Spontaneous Reactivation of HSV-1 from Latency. Journal of Virology, 68, 8045-8055. https://doi.org/10.1128/JVI.68.12.8045-8055.1994

[32] Whisnant, A.W., Jurges, C.S., Hennig, T., et al. (2020) Integrative Functional Genomics Decodes Herpes Simplex Virus 1. Nature Communications, 11, 2038. https://doi.org/10.1038/s41467-020-15992-5

[33] Nakashima, H., Nguyen, T., Kasai, K., et al. (2018) Toxicity and Efficacy of a Novel GADD34-Expressing Oncolytic HSV-1 for the Treatment of Experimental Glioblastoma. Clinical Cancer Research, 24, 2574-2584. https://doi.org/10.1158/1078-0432.CCR-17-2954

[34] Bernstock, J.D., Vicario, N., Li, R., et al. (2020) Safety and Efficacy of Oncolytic HSV-1 G207 Inoculated into the Cerebellum of Mice. Cancer Gene Therapy, 27, 246-255. https://doi.org/10.1038/s41417-019-0091-0

[35] Todo, T., Martuza, R.L., Rabkin, S.D., et al. (2001) Oncolytic Herpes Simplex Virus Vector with Enhanced MHC Class I Presentation and Tumor Cell Killing. Proceedings of the National Academy of Sciences of the United States of America, 98, 6396-6401. https://doi.org/10.1073/pnas.101136398 
[36] Kelly, K.J., Wong, J. and Fong, Y. (2008) Herpes Simplex Virus NV1020 as a Novel and Promising Therapy for Hepatic Malignancy. Expert Opinion on Investigational Drugs, 17, 1105-1113. https://doi.org/10.1517/13543784.17.7.1105

[37] Patel, D.M., Foreman, P.M., Nabors, L.B., et al. (2016) Design of a Phase I Clinical Trial to Evaluate M032, a Genetically Engineered HSV-1 Expressing IL-12, in Patients with Recurrent/Progressive Glioblastoma Multiforme, Anaplastic Astrocytoma, or Gliosarcoma. Human Gene Therapy Clinical Development, 27, 69-78. https://doi.org/10.1089/humc.2016.031

[38] Maclean, A.R., Ul-Fareed, M., Robertson, L., et al. (1991) Herpes Simplex Virus Type 1 Deletion Variants 1714 and 1716 Pinpoint Neurovirulence-Related Sequences in Glasgow Strain 17+ between Immediate Early Gene 1 and the "a" Sequence. Journal of General Virology, 72, 631-639.

https://doi.org/10.1099/0022-1317-72-3-631

[39] Andtbacka, R.H., Kaufman, H.L., Collichio, F., et al. (2015) Talimogene Laherparepvec Improves Durable Response Rate in Patients with Advanced Melanoma. Journal of Clinical Oncology, 33, 2780-2788. https://doi.org/10.1200/JCO.2014.58.3377

[40] Ren, J., Gwin, W.R., Zhou, X., et al. (2017) Adaptive T Cell Responses Induced by Oncolytic Herpes Simplex Virus-Granulocyte Macrophage-Colony-Stimulating Factor Therapy Expanded by Dendritic Cell and Cytokine-Induced Killer Cell Adoptive Therapy. Oncoimmunology, 6, e1264563.

https://doi.org/10.1080/2162402X.2016.1264563

[41] Tanaka, R., Goshima, F., Esaki, S., et al. (2017) The Efficacy of Combination Therapy with Oncolytic Herpes Simplex Virus HF10 and Dacarbazine in a Mouse Melanoma Model. American Journal of Cancer Research, 7, 1693-1703.

[42] Wang, Y.Y., Lyu, Y.N., Xin, H.Y., et al. (2019) Identification of Putative UL54 (ICP27) Transcription Regulatory Sequences Binding to Oct-1, v-Myb, Pax-6 and Hairy in Herpes Simplex Viruses. Journal of Cancer, 10, 430-440. https://doi.org/10.7150/jca.29787

[43] Liu, X.Q., Xin, H.Y., Lyu, Y.N., et al. (2018) Oncolytic Herpes Simplex Virus Tumor Targeting and Neutralization Escape by Engineering Viral Envelope Glycoproteins. Drug Delivery, 25, 1950-1962. https://doi.org/10.1080/10717544.2018.1534895

[44] Cheng, J.T., Wang, Y.Y., Zhu, L.Z., et al. (2020) Novel Transcription Regulatory Sequences and Factors of the Immune Evasion Protein ICP47 (US12) of Herpes Simplex Viruses. Virology Journal, 17, 101.

https://doi.org/10.1186/s12985-020-01365-3

[45] Goins, W.F., Huang, S., Hall, B., et al. (2020) Engineering HSV-1 Vectors for Gene Therapy. Methods in Molecular Biology, 2060, 73-90. https://doi.org/10.1007/978-1-4939-9814-2 4

[46] Kanai, R., Zaupa, C., Sgubin, D., et al. (2012) Effect of Gamma34.5 Deletions on Oncolytic Herpes Simplex Virus Activity in Brain Tumors. Journal of Virology, 86, 4420-4431. https://doi.org/10.1128/JVI.00017-12

[47] Arias, C., Weisburd, B., Stern-Ginossar, N., et al. (2014) KSHV 2.0: A Comprehensive Annotation of the Kaposi's Sarcoma-Associated Herpesvirus Genome Using Next-Generation Sequencing Reveals Novel Genomic and Functional Features. PLOS Pathogens, 10, e1003847.

https://doi.org/10.1371/journal.ppat.1003847 
[48] Erhard, F., Halenius, A., Zimmermann, C., et al. (2018) Improved Ribo-seq Enables Identification of Cryptic Translation Events. Nature Methods, 15, 363-366. https://doi.org/10.1038/nmeth.4631

[49] Kanerva, A., Nokisalmi, P., Diaconu, I., et al. (2013) Antiviral and Antitumor T-Cell Immunity in Patients Treated with GM-CSF-Coding Oncolytic Adenovirus. Clinical Cancer Research, 19, 2734-2744. https://doi.org/10.1158/1078-0432.CCR-12-2546

[50] Patel, M.R. and Kratzke, R.A. (2013) Oncolytic Virus Therapy for Cancer: The First Wave of Translational Clinical Trials. Translational Research, 161, 355-364. https://doi.org/10.1016/j.trsl.2012.12.010

[51] Forbes, N.E., Abdelbary, H., Lupien, M., et al. (2013) Exploiting Tumor Epigenetics to Improve Oncolytic Virotherapy. Frontiers in Genetics, 4, 184.

https://doi.org/10.3389/fgene.2013.00184 